\title{
The translation that keeps pace with the times and foreign language education
}

\author{
Yike He \\ (Northwestern University for Nationalities, Lanzhou, Gansu, 421000, China)
}

\begin{abstract}
Translation and foreign language teaching have always been inseparable. Without translation, there is no educational materials source; without education, there is no continuation of translation. In the following content, the following article will try to analyze the relationship between translation and foreign language education, the development status, and the training of translation professionals in China from the perspective of the relationship between translation and foreign language teaching and the current situation.
\end{abstract}

Keywords: translation career, foreign language education, translation teaching, the history of translation, pragmatism, and formalism in teaching

About the author: He YiKe(2001 ), female, from Hengyang in Hunan Province, an undergraduate, engaged in Arabic studies

DOI : $10.36012 /$ fhe. v2i3. 2771

\section{Introduction}

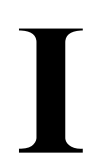

$f$ we are going to talk about the translation career in China, it is a long process. Whether the earliest origin can be traced back to two thousand years ago or three thousand years ago, it remains to be determined. The translation project in ancient times is very different from the current one. At that time, the translators were also called "Tongue people", and their social status was petty and low. The work they did was basically just for a livelihood and had nothing to do with academics. This situation has turned a corner in modern times. A commonly accepted view in the academic circles is that the true modern translation career in China started in the second half of the 19 th centu- $^{-}$ ry, with the Jingshi Tongwen Museum established in 1862. Since translation is the foundation and ultimate goal of all foreign language education. In 1950 , the Ministry of Education issued a draft curriculum for the Department of Foreign Languages of the College of Humanities of Colleges and Universities. It determined that the training goal of foreign language talents was "to cultivate students' proficiency in the use and translation of foreign languages so that they can become translators, foreign language teachers, and talents who study foreign literature." Based on this educational plan, the foreign language majors in colleges and universities have trained generations of high-level new talents for our country since the founding of the People's Republic of China, devoted to diplomacy, economics and trade, culture, education, news, and communication, writing, military, and It has made outstanding contributions to my country's socialist development in many fields such as technology and infrastructure. But nothing is perfect. There are still deficiencies in the development of foreign language education in Chinese universities, which are mainly manifested in two aspects, which are: High - level foreign language talents with strong language skills, familiar translation skills, and strong knowledge reserves in China are still a minority; and in the context of continuous development and expansion of foreign languages, the practicality of the fixed teaching system and content is facing decline.

\section{The first aspect}


The shortage problem of high - level foreign language talents in China. For a long time, China has paid far less attention to translation than the four skills "listening, speaking, reading and writing". In the inherent test mode of compulsory education, a test paper with a full score of 150 points, the listening comprehension tests the ability to listen, which usually accounts for about 30 points; reading comprehension examines the ability to read, which often includes three items: passage comprehension, word selection, and cloze filling, which account for about 70 points; and there are short essay correction and composition examine the ability of writing, which account for 30 points. But we can't find a section to examine translation ability from a complete national college entrance examination foreign language test paper. It can be seen that in the inherent basic foreign language education model and educational philosophy, translation does not form an independent set of systems, but is attached to the four language abilities of "listening, conversation, reading and writing ". Translation ability is generally regarded as the ability that can be learned incidentally as long as the above four skills are mastered. This concept has been deeply rooted in the teaching of professional foreign languages in Chinese universities and has become a misunderstanding in the process of foreign language education. However, translation is a purposeful, complex, and unique comprehensive activity that involves the coordinated application of various knowledge and skills. Language ability is only the basis of translation ability, and it cannot summarize the composition of translation ability, let alone replace it. The translation is a very delicate science. It is not only a skill but also a precise mastery of professional knowledge. It also requires a rich knowledge reserve of translators. Translation is roughly divided into written translation and interpretation. Interpretation is often considered more difficult than written translation. The main reason is that the amount of words processed by the interpreter is much larger than that of written translation per unit time. Taking Arabic translation as an example, the number of words processed by one hour of simultaneous interpretation is about 9,000 to 10,000 words. In contrast, the daily translation capacity of the United Nations contracted translators is generally 2,000 to 3,000 words. and it is precisely because of such a huge amount of information processing that interpreters are often replaced every 15 to 20 minutes to avoid emergencies caused by brain fatigue and excessive stress. Due to the profession's particularity and the rigor of the work, the training of translation talents is completely different from the training of general foreign language education. General foreign language education cannot replace specialized translation skills training. A professional translation practitioner must be proficient in the linguistic laws, sentence structure, and correspondence between Chinese and foreign languages, proficient in applying various translation skills, and possess excellent physical, psychological, moral and political qualities and broad knowledge surface. Therefore, we can say that a qualified translator must be a qualified foreign language talent, but a qualified foreign language talent is not the same as a qualified translator. Today's traditional foreign language education is not enough to train a professional translator. Take the national translation professional qualification test Arabic second-level written translation test syllabus as an example. The Arabic - Chinese translation speed is required to be 400 to 500 words per hour; the Chinese to Arabic translation speed is 300 to 400 Chinese characters per hour, and the translation is faithful to the original text. The language is relatively standard, the words are correct, the questions are fluent, and there are no too many grammatical errors. However, in terms of the arrangement of translation courses offered by colleges and universities so far, many colleges and universities may not systematically offer relevant courses until the third year, and even after the courses are opened, the translation training intensity of one or two class hour per week per semester is far from enough. A training session that lasts one to two hours in the translation and interpretation courses provided in the foreign language syllabus can only be said to be a superficial touch, no matter in terms of training intensity or depth. The training of professional translators requires written translation training of more than 10,000 characters or 
hundreds of thousands of hours of interpreting training before they can grow into applied interpreters and translators who meet the basic requirements, followed by high-level translation professionals who tend to be All-round translation professionals or All - round translation professionals. The basic literacy required by high - level translation professionals covers three aspects: language skills and knowledge, encyclopedia knowledge (including international politics, economy, trade, law, local customs, current affairs, etc.), and translation skills (including knowledge related to the translation career, basic translation requirements, and standards, translation professional quality education, etc. ). Strict and prudent translation standards and training programs that require a long time and huge human investment determine that high-level translators cannot "mass production". Unfortunately, our country is still in the groping stage and has not yet formed a systematic teaching training program for advanced and highlevel translators.

In addition, there are also classifications of translators, which are interpreters and translation professionals. As a skill that is several times more difficult than written translation, professional interpreters need to have a more precise and quick grasp of the sentence structure and language habits of the original language and the target language. Interpreters often need to prepare sufficient relevant materials for 20 days to a month even before an international conference that is only half an hour long and has the psychological quality and ability to play and deal with emergencies on the spot. The amount of work for interpretation is huge. If you want to translate quickly and accurately, you must abide by the principle of almost no translation, that is: Do not translate polite modifiers. For example, do not translate too much in the morning of "Celebrate with the country" in a speech; Do not translate long and aimless talks; Do not translate too many repetitions, etc. However, there is no standard for the above situations. That is to say, the translator must make his judgment, which tests the translator's accurate mastery of the subject and core of the translation work. In addition, translators must be responsible for their translation results. After the translation, if the $\mathrm{O}^{-}$ riginal purpose is not achieved, and there are errors in the translation process, and even if there is the economic loss in the translation of economic and trade cooperation, these errors will be borne by the translator. To sum up, the insufficient training of high - level translators, extremely high professional requirements, and heavy work pressure are all the difficulties in successfully shaping a high - level all - round translator in China.

\section{The second aspect}

In the context of continuous development and expansion of foreign languages, the practicability of the fixed teaching system and content is facing a decline. According to the country's development needs and actual conditions over the years, most of the final destination of foreign language teaching is to provide the country with foreign language talents to serve various fields such as Sino-foreign exchanges, international exchange services, and international aid development, and socialist economic development, and create fruitful results for our country in the fields of economy, international relations, academics, and literature and art. Therefore, cultivating useful foreign language talents for the social and economic development of our country is the primary task of our foreign language education, so that foreign language teaching in our country must ensure its practicality, strive for the supremacy of practice, and put an end to " talking on paper". The current foreign language teaching has significant shortcomings in this respect, which is reflected explicitly in the fact that if only the contents of the books were tested in the exam, then the student will answer them fluently; Once what is not in the book was examined, they will suddenly be impossible to write, let alone speak it out. The teaching mode confined to books makes students' thinking rigid. Their first reaction when organizing sentences is to apply the inherent sentence patterns in the book. The simplest example in everyday English is :

- How are you?

- I'm fine, thank you, and you?

Everyone can blurt out this sentence without thinking. From the perspective of the general public, this is a kind of primary education. Still, for 
foreign language talents, it is a kind of rigid thinking and stagnation of resource updates. To say that I am fine can not only use I'm fine, but also I feel great; I am in a good mood; Everything around me goes well recently, and so on. If a foreign language professional only knows "I'm fine", and he inevitably fall into a vulgar and mediocre situation.

Languages are constantly being updated., the most prominent example is the mutual absorption between languages, which also refers to the introduction of foreign words. Foreign words refer to words that are transliterated or literally translated from other languages. The main methods of $\mathrm{ab}^{-}$ sorption are transliteration and free translation. Strictly speaking, foreign words only include transliterated words with homophonic components. In a broad sense, as long as one of the sounds, forms, and meanings of words is borrowed from the languages of other nations, it belongs to the category of foreign words. The existence of loan words proves the vitality of this language and reflects its inclusiveness, adaptability and reproducibility. If all languages in the world want to develop, they need the help of loan words. A large number of loan words existing in all the ancient but vivid languages in the world. As the most widely used language in the world, English words are borrowed by many languages, such as aspirin, coffee, mosaic, hamburger, etc., in Chinese. Arabic is no exception, such as التكنولوجيا, which is a transliteration from English Technology ; الكمبيوتر, which is a transliteration of computer in English; and ديمقر اطية, which is an evolution from democracy in English. These foreign words do not conform to the lexical rules in Arabic and have no root source. The beginners will definitely be at a loss when they encounter them for the first time. Not only do they not know what it means, but they may not even be able to read it. With the progress of the times and the development of various fields of science and technology, more and more new words and foreign words will continue to emerge, and the immutable teaching materials, teaching content, and teaching mode will inevitably be out of touch with the actual situation. This situation is particularly obvious in the minor language majors of Chinese universities. Take the $\mathbf{u}^{-}$ nified teaching material for basic courses in Arabic as an example. The textbook has not undergone major changes since it was published in 2002. Until 2020, nearly 20 years have passed, a large part of the content has fallen behind the times. What's worse, this situation will not improve in the short term. Since the purpose of foreign language teaching is to cultivate professional foreign language talents for the motherland, and Its slogan is "speak foreign languages well and be an exceptional Chinese", and at the same time, the language storage of foreign languages has been increasing day by day., how to firmly grasp the practicality of languages, and avoid the situations where "students have studied for four years but found that many times they can't speak", it is one of the key points that foreign language education needs to pay attention to.

It can be seen from the above examples that there are indeed many problems in foreign language teaching, real needs are often neglected in foreign language teaching. On the contrary, long - formed theories and literature are put first. The actual level of the students is ignored. The focus of the examination seems to be whether the students are proficient in the book's knowledge until the test and do not care whether the knowledge is really transformed into an internalized knowledge reserve. Therefore, most students passively study to pass the exam. Whether they can digest knowledge is a secondary concern. The most important thing is that they can remember knowledge for a short time. They end up with a weak foundation and weak ability. When they work independently, the knowledge they have learned is not available, and the one they need to use has not been learned or forgotten. This has caused a certain degree of waste of time, energy, manpower, and funds to the country and universities. It's not that every foreign language graduate of a university must engage in a foreign language - related career after graduation. As long as it is a foreign language graduate who can continue to create a certain value in a certain field, it can be counted as a talent and resource at the human resources level. However, 
in most cases, foreign language teaching that sticks to formalism is real and has many drawbacks. As the saying goes: "We have professionals in charge of different aspects. " We cannot ask everyone to study language and literature, language style, or the writing style of a certain writer. Not to mention that many students who have problems with memorizing vocabulary and grammar are also tired of remembering literary knowledge that they are very likely not to use in the future. Those students even struggle to write short essays, yet they have to understand and study obscure literature blindly. What's more, English majors of some colleges and universities even offer courses on the appreciation of British and American films and television. The form of class is just watching movies. So what is the significance of this class? And where is its practicality?

Fortunately, the country seems to have gradually realized the drawbacks of formalism and has gradually reduced the opening of such unnecessary courses in colleges and universities, and the time and energy of teachers and students can be more and more concentrated on the main courses. This is undoubtedly a good thing for the development of China's foreign language education and translation careers. The reason is that translation is the best examination of teaching results because it cannot be memorized by rote or be perfected and avoided, and there is no formula to apply. It is "practical. " With it as the starting point, foreign language education has an inexhaustible source and can maintain its vitality. On this basis, we can research theory, foreign literature, foreign history, foreign state system and learn from others. The purpose of serving the country with foreign languages will be truly achieved.

\section{3. summary}

This article mainly discusses several major issues in translation and foreign language education: 1 . There are still deficiencies in my country's professional translation skills training, as well as professional translation training and training programs.

2. Foreign language education does not represent and cannot replace translation education. 3. Under the influence of multiple factors, my country's high - level translators are still in short supply. 4. The update of teaching mode is much slower than the speed of continuous expansion of foreign language teaching content. It is likely that the practicality of teaching results will decline. This situation is particularly obvious in the teaching of small languages.

Translation has brought teaching materials and teaching sources to foreign language education. Only with accurate translation can there be outstanding foreign language education, and only with positive foreign language education can a steady stream of fresh blood be delivered to the translation career. Judging from the current situation in our country, the undergraduate degree of foreign language department is still the main source of translation talents in my country. Studying a series of problems in translation teaching for foreign language majors has profound practical significance.

\section{References}

[1] Translation and Language Teaching [J]. Translation in China, 2007(04):11-12.

[2] Mou Xudian. On Translation and Foreign Language Teaching $[\mathrm{J}]$. Foreign Languages, 1986(1):83-88.

[3] Translation Competence: The Basis of Translation Teaching $[\mathrm{J}]$. Foreign Languages and Foreign Language Teaching, 2007 (No.4).

[4] National Professional Qualification (Level) Examination for Translation and Interpretation (National Professional Qualification) - Arabic Translation and Translation (Level 2)

[5] https://baike. baidu. com/item/ / $2475423 \mathrm{fr}=$ Aladdin foreign words

[6] https://wenku. baidu. com/view/1329f991f90f76c660 371a5b. html《Sino - Arab Cultural Exchange》

[7] Xu Lu. A Brief Analysis of English Loanwords Borrowing in Modern Chinese $[\mathrm{J}]$. Northern Literature (next issue), 2011, $000(009)$ :165-165.

[8] Wang Xiaonong. Translation Profession Competence and Translation Teaching for Foreign Language Profession $[\mathrm{J}]$. Journal of Tangshan Normal University, 2009(01):163-166. 